\title{
ANALISIS YURIDIS TERHADAP MENINGGALNYA MUDHARIB DALAM AKAD PEMBIAYAAN MUDHARABAH PADA PERBANKAN SYARIAH
}

\author{
Vendra Irawan \\ Universitas Muhammadiyah Yogyakarta
}

$\triangle$ Corresponding Author:

Nama Penulis: Vendra Irawan

E-mail: vendrairhawan151@gmail.com

\section{Abstract}

The purpose of this research is to examine the legal consequences of the death the capital manager (mudharib) in the mudharabah financing contract. The type of research used is normative juridical with a statute approach and a conceptual approach. The sources of legal material in this study are from primary legal material and secondary legal material. The results of the analysis of this study are that when the capital manager dies in the mudharabah financing contract in Islamic banking, the agreement made between the capital owner and the capital manager ends automatically. The point is that the legal relationship between the capital owner and the capital manager has been broken up since then and has also resulted in the breaking up of rights and obligations among the parties that made the agreement. While all forms of risk in the mudharabah contract are borne by the owner of the capital, unless the capital manager is proven to have made a deliberate mistake, negligent or violated the agreement. Since the capital manager has died in the mudharabah financing contract, the capital owner may not sue his familys to pay the remaining payment from the financing because mudharabah is not a debt agreement. To restore the capital, the owner of the capital that has not been paid by the deceased capital manager is to sell his capital management business, or if the business is still running, the familys may continue the business of the deceased capital manager with the agreement of the capital owner.

Keywords: Legal analysis; The Death of Capital manager; Mudharabah

\section{Abstrak}

Penelitian ini bertujuan untuk mengkaji akibat hukum dari meninggalnya mudharib dalam akad pembiayaan mudharabah. Jenis penelitian yang penulis gunakan dalam penelitian ini adalah yuridis normatif dengan pendekatan perundang-undangan dan pendekatan konseptual. Sumber bahan hukum dalam penelitian ini adalah dari bahan hukum primer dan bahan hukum sekunder. Hasil analisis dari penelitian ini adalah pada saat mudharib meninggal dunia dalam akad pembiayaan mudharabah pada perbankan syariah, maka perjanjian yang dibuat antara shahib al-maal dengan mudharib menjadi berakhir dengan sendirinya. Maksudnya ialah bahwa hubungan hukum antara shahib al-maal dengan mudharib menjadi putus semenjak itu juga dan berakibat pula pada putusnya hak dan kewajiban diantara para pihak yang melakukan perjanjian tersebut. Sedangkan segala bentuk risiko dalam 
akad mudharabah ditanggung oleh shahib al-maal, kecuali jika mudharib terbukti melakukan kesalahan yang disengaja, lalai atau menyalahi kesepakatan. Semenjak mudharib meninggal dunia dalam akad pembiayaan mudharabah, maka shahib al-maal tidak diperkenankan menuntut ahli warisnya untuk membayar sisa pembayaran dari pembiayaannya karena mudharabah bukanlah perjanjian utang-piutang. Untuk mengembalikan modalnya shahib al-maal yang belum dibayarkan oleh mudharib yang telah meninggal dunia adalah dengan menjual usahanya mudharib, atau apabila usahanya masih berjalan, maka ahli warisnya boleh melanjutkan usaha dari mudharib yang meninggal dunia tersebut dengan kesepakatan dari shahib almaal.

Kata kunci: Analisis Yuridis; Meninggalnya Mudharib; Mudharabah

\section{PENDAHULUAN}

Maraknya perbankan syariah pada zaman milenial ini bukanlah suatu gejala baru dalam dunia Islam. Perkembangan perbankan syariah ini mulai muncul sekitar pertengahan abad $20 \mathrm{M}$ yang ditandai dengan semangat hijrah dari berbagai kalangan, seperti: Ulama, akademisi maupun praktisi untuk mengenalkan dan mengembangkan sektor ekonomi syariah tersebut. Hal ini juga dilandasi oleh ayat-ayat Al-Qur'an dan Hadits yang menjelaskan bahwa bunga bank itu termasuk riba dan diharamkan karena adanya ketidakadilan di dalamnya, maka lahirlah perbankan model baru seperti perbankan syariah ini untuk memperbaiki sistem perbankan yang telah ada sebelumnya. Perkembangan perbankan syariah ini juga diperkuat dengan dukungan dari berbagai negara berbasis Islam kuat, seperti: Arab Saudi, Pakistan, Mesir, Kuwait, Yordania, Sudan, Bahrain, Iran, Uni Emirat dan lain sebagainya termasuk Indonesia sendiri sebagai negara yang mayoritas penduduknya adalah muslim.

Kehadiran perbankan syariah di sektor ekonomi ini sangat membantu masyarakat dalam memenuhi kebutuhan hidupnya, karena dengan sistem ini bisa menghapuskan berbagai kesenjangan yang ada di masyarakat. Tentunya hal ini juga harus diikuti oleh aturan hukum yang jelas dan rinci agar terciptanya kepastian hukum, kemanfaatan dan keadilan bagi masyarakat. Antara hukum dan ekonomi tersebut mempunyai hubungan yang sangat erat, karena mempunyai hubungan timbal balik antara keduanya seperti dua sisi mata uang. Maka, sistem ekonomi suatu bangsa akan tercermin dalam sistem hukumnya (Musjtari, 2016).

Setelah ditetapkannya Undang-Undang Nomor 10 Tahun 1998 tentang Perbankan, sektor perbankan Indonesia dibagi kepada bank yang menjalankan kegiatan usaha secara konvensional dan bank yang menjalankan kegiatan usaha berdasarkan prinsip syariah (bank syariah). Bank syariah yang kegiatan usahanya berlandaskan prinsip syariah 
dijalankan dengan menggunakan sistem bagi hasil (Muhammad, 2005). Dengan demikian, setiap produk yang dihasilkan oleh bank syariah haruslah berjalan dengan mempedomani konsep syariah. Salah satu diantara berbagai macam produk yang dikenalkan oleh bank syariah kepada masyarakat luas yang menggunakan jasa perbankan syariah dalam produk financing (pembiayaan atau penyaluran dana) ialah pembiayaan bagi hasil dengan menggunakan akad mudharabah.

Mudharabah merupakan perjanjian untuk menjalankan suatu kegiatan usaha antara bank sebagai pemilik modal (shahib al-maal) dengan nasabah sebagai pengelola dana (mudharib). Yang mana dalam hal ini bank sebagai pemilik modal membantu pembiayaan suatu usaha atau proyek dan pengusaha sepakat untuk mengelola usaha tersebut dengan sistem bagi hasil berdasarkan perjanjian yang disepakati oleh masing-masing pihak. Pemilik modal tidak diperbolehkan untuk ikut campur secara langsung dalam mengelola suatu usaha tersebut, akan tetapi diperkenankan untuk memberikan usulan dan pengawasan (Sumitro, 2004). Laba/keuntungan yang didapatkan dari kegiatan usaha dalam akad mudharabah tersebut dibagi berdasarkan nisbah bagi hasil yang dijelaskan dalam kontrak yang ditandatangani para pihak, kemudian jika dalam usaha itu terjadi kerugian yang disebabkan bukan karena kelalaian ataupun kesengajaan pengelola modal, maka kerugian tersebut ditanggung sendiri oleh pemilik modal. Akan tetapi, apabila kerugian itu disebabkan karena adanya unsur kesalahan yang disengaja atau kelalaian dari pengelola modal, maka pengelola modal (mudharib) harus bertanggungjawab dari kerugian usaha yang dijalankannya itu (Sudarsono, 2004).

Pada Bagian Ketiga Angka (3) Fatwa Dewan Syariah Nasional Majelis Ulama Indonesia Nomor 07/DSN/MUI/IV/2000 tentang Pembiayaan Mudharabah dijelaskan "Pada dasarnya, dalam mudharabah tidak ada ganti rugi, karena pada dasarnya akad ini bersifat amanah (yad al-amanah), kecuali akibat dari kesalahan disengaja, kelalaian, atau pelanggaran kesepakatan". Berdasarkan Fatwa DSN-MUI diatas, maka keuntungan yang diperoleh dalam akad mudharabah dibagi berdasarkan nisbah yang telah disepakati ketika akadnya dan kerugian ditanggung oleh pemilik modal, maka ketika terjadi suatu kerugian tidak tepat kiranya bank sebgai pemilik modal (shahib almaal) meminta agunan dari pengelola dana (mudharib) untuk menutupi kerugian yang terjadi, karena akad mudharabah pada hakikatnya bukanlah merupakan perjanjian pinjam-meminjam maupun perjanjian utang-piutang diantara para pihak, akan tetapi merupakan suatu akad kerjasama untuk menjalankan suatu kegiatan usaha antara pemilik modal dengan pengelola dana dengan sistem bagi hasil yang mereka sepakati. 
Fungsi agunan dalam akad mudharabah pada perbankan syariah ialah untuk menjamin pelaksanaan akad mudharabah sesuai dengan kesepakatan yang dibuat oleh para pihak diawal perjanjian, yakni antara shahib al-maal dengan mudharib. Sedangkan fungsi agunan pada perbankan yang menjalankan kegiatan usaha secara konvensional adalah sebagai penjamin atas utang-piutang yang terjadi antara kreditur dengan debitur (Yhu'nanda, 2014). Jadi, sangatlah berbeda antara fungsi agunan pada perbankan syariah dengan perbankan konvensional. Akad mudharabah ini sangat mengedepankan kepercayaan (amanah) antara masing-masing pihak dengan menjunjung keadilan serta menuntut kejujuran yang tinggi demi menjaga kepentingan bersama. Oleh karena itu, apabila terjadi kerugian yang mana hal tersebut murni bukan disebabkan karena kelalaian, kesalahan yang disengaja dan pelanggaran perjanjian oleh mudharib, maka agunan yang ada tersebut tidak dapat disita.

Berdasarkan uraian permasalahan yang telah disebutkan diatas, maka peneliti ingin melakukan kajian yang lebih mendalam tentang "Analisis Yuridis Terhadap Meninggalnya Mudharib dalam Akad Pembiayaan Mudharabah Pada Perbankan Syariah". Penelitian ini bertujuan untuk mengkaji bagaimana akibat hukum dari meninggalnya mudharib dalam akad pembiayaan mudharabah pada Perbankan Syariah. Tujuan kedua ialah untuk mengkaji apakah dengan meninggalnya mudharib tetap berkewajiban membayar sisa pembayaran dari pembiayaannya.

\section{KAJIAN PUSTAKA}

Istilah bagi hasil dalam ekonomi syariah sering dikenal dengan istilah mudharabah. Orang-orang Hijaz mengenal Mudharabah dengan istilah qiradh/muqaradhah. Sedangkan istilah mudharabah sendiri berasal dari bahasa yang digunakan oleh bangsa Irak. Mudharabah merupakan perjanjian kerjasama antara pemilik modal (shahib al-maal) yang mengamanahkan dananya kepada pihak kedua yakni disebut sebagai pengelola dana (mudharib) dengan tujuan untuk menjalankan suatu kegiatan usaha perdagangan, yang mana mudharib menyumbangkan tenaga, waktunya dan mengelola perkongsian tersebut berdasarkan proporsi yang disepakati oleh masing-masing pihak sebelumnya. Kerugian dan risiko yang muncul dalam mudharabah ditanggung sendiri oleh pemilik modal (shahib al-maal), kecuali kerugian itu terjadi karena kelalaian, kesalahan yang disengaja dan pelanggaran perjanjian oleh mudharib. Salah satu ciri utama dari akad mudharabah ini ialah apabila mendapatkan laba/keuntungan, maka akan dibagi antara shahib al-maal dan mudharib berdasarkan nisbah yang mereka sepakati diawal kontrak (Saeed, 2004). 
Menurut Ibnu Rusyd dari Mazhab Maliki berpendapat bahwa akad mudharabah dalam Islam hukumnya dibolehkan, karena hal ini bisa saling membantu antara orang yang mempunyai modal (shahib al-maal) dengan pengelola dana (mudharib) untuk menjalankan suatu kegiatan usaha. Jadi, Ibnu Rusyd memandang bahwa kebolehan akad mudharabah ini merupakan suatu kelonggaran yang khusus (Rusyd:78). Karena mudharabah sudah menjadi kebiasaan dan telah dipraktikkan oleh ummat Islam sejak periode awal era Islam meskipun tidak disebutkan secara langsung dalam Al-Qur'an atau Sunnah.

Secara garis besar akad mudharabah dibagi menjadi 2 (dua) jenis, yaitu: (1) Mudharabah Muthlaqah, ialah akad mudharabah yang sifatnya mutlak dimana shahib al-maal tidak menetapkan restriksi atau syarat-syarat tertentu kepada mudharib. (2) Mudharabah Muqayyadah, yakni pemilik modal (shahib al-maal) membatasi atau memberi syarat kepada pengelola dana (mudharib) dalam pengelolaan modalnya, misalnya hanya untuk menjalankan mudharabah pada sektor tertentu, waktu, cara ataupun tempat tertentu saja (Antonio, 1999).

Rukun dalam akad mudharabah menurut Jumhur Ulama adalah sebagai berikut: Pertama, Dua orang yang melakukan akad (al-aqidani); Kedua, Modal (ma'qud 'alaih); Ketiga, Sighat akad (ijab dan qabul) (Naf'an, 2014).

\section{METODE PENELITIAN}

Pada penelitian ini penulis menggunakan jenis penelitian Yuridis Normatif. Penelitian Yuridis Normatif merupakan suatu metode penelitian hukum dengan meneliti bahan pustaka atau data sekunder (Soekanto, 2001). Adapun tujuan dari penelitian hukum ini ialah untuk mengidentifikasi aturan hukum, asas-asas, prinsip-prinsip dan konsep-konsep yang digunakan untuk mengkaji akibat hukum dari meninggalnya mudharib dalam akad pembiayaan mudharabah pada Perbankan Syariah.

Kemudian penelitian ini dilakukan dengan menggunakan Pendekatan Perundang-Undangan (statute approach) dan Pendekatan Konseptual (conceptual approach). Untuk pendekatan perundang-undangan (statue approach) dilakukan dengan menyelidiki aturan-aturan hukum yang berhubungan dengan konsep mudharabah pada perbankan syariah. Sedangkan pendekatan konseptual (conceptual approach) dilakukan untuk memahami konsep-konsep yang berkaitan dengan akibat hukum dari meninggalnya mudharib dalam akad pembiayaan mudharabah pada perbankan syariah.

Sumber bahan hukum yang digunakan dalam penelitian ini berasal dari bahan hukum primer dan bahan hukum sekunder. Bahan hukum primer 
didapatkan dari berbagai peraturan perundang-undangan yang berkaitan dengan penelitian ini, antara lain: Undang-Undang Nomor 21 Tahun 2008 tentang Perbankan Syariah, Undang-Undang Nomor 10 Tahun 1998 tentang Perbankan perubahan atas Undang-Undang Nomor 7 Tahun 1992, UndangUndang Nomor 3 Tahun 2004 tentang Bank Indonesia, Fatwa Dewan Syariah Nasional Nomor 07/DSN/MUI/IV/2000 tentang Pembiayaan Mudharabah, Peraturan Bank Indonesia Nomor: 9/19/PBI/2007 tentang Pelaksanaan Prinsip Syariah dalam Kegiatan Penghimpunan Dana dan Penyaluran Dana Serta Pelayanan Jasa Bank Syariah, Buku Kedua Kompilasi Hukum Ekonomi Syariah (KHES). Sedangkan bahan hukum sekunder pada penelitian ini bertujuan untuk membantu penulis dalam menganalisis dan memberikan pemahaman yang berkaitan dengan tema penelitian, antara lain: Tafsir AlQur'an, Sunnah, Ijma', hasil penelitian, jurnal-jurnal, buku-buku, artikel ilmiah, makalah hasil seminar dan lain sebagainya.

Adapun dalam hal pengumpulan data-data metode yang digunakan dalam penelitian ini ialah dengan melakukan studi kepustakaan, yakni: mempelajari, memahami dan mengkaji Tafsir Al-Qur'an, Hadits, Ijma', peraturan perundang-undangan, jurnal ilmiah, buku-buku dan tulisan para pakar atau cendekiawan yang berkaitan dengan tema penelitian ini.

Kemudian metode analisis data yang digunakan dalam penelitian ini ialah dengan metode deskriptif kualitatif. Maksud dari metode deskriptif kualitatif adalah untuk menjelaskan atau menjabarkan dari hasil penelitian mengenai akibat hukum dari meninggalnya mudharib dalam akad pembiayaan mudharabah pada perbankan syariah.

\section{HASIL DAN PEMBAHASAN}

\section{Akibat Hukum dari Meninggalnya Mudharib dalam Akad Pembiayaan Mudharabah Pada Perbankan Syariah}

Ummat Islam sendiri telah mengenal akad mudharabah sejak masa Nabi Muhammad SAW, bahkan bangsa Arab pun telah melaksanakan akad ini sebelum turunnya Islam. Nabi Muhammad SAW telah mempraktikkan akad mudharabah ini dengan Khadijah ketika beliau menjalankan usaha perdagangan secara bersama-sama pada waktu itu (Karim, 2004). Apabila ditinjau dari sisi hukum Islam, maka sistem bagi hasil dengan menggunakan akad mudharabah ini sah dan dibolehkan baik menurut Al-Qur'an, Sunnah, Ijma' ataupun Qiyas.

Akad mudharabah yang dipraktikkan antara Khadijah dengan Nabi Muhammad SAW pada waktu itu Khadijah mempercayakan barang-barang dagangannya kepada Nabi Muhammad SAW untuk dijual ke luar negeri. Mengenai contoh kasus tersebut dapat kita lihat bahwasannya Khadijah 
berperan sebagai pemilik modal (shahib al-maal), sedangkan Nabi Muhammad SAW sendiri berperan sebagai orang yang menjalankan kegiatan usahanya (mudharib) (Naf'an, 2014).

Mudharabah merupakan suatu bentuk akad kerjasama antara dua pihak yang mana satu pihak berperan sebagai pemilik modal (shahib al-maal) dengan mempercayakan sejumlah modalnya untuk dikelola oleh pihak kedua, yakni oleh pelaksana usaha atau pengelola dana tersebut (mudharib) dengan tujuan untuk mendapatkan laba/keuntungan dari usaha yang dijalankan itu (Karim, 2004). Kemudian menurut pengertian yang lainnya juga dijelaskan bahwa akad mudharabah ialah suatu persetujuan perkongsian antara harta atau modal dari salah satu pihak dengan kerja/pelaksana dari pihak lain (Ibrahim, 2002).

Akad mudharabah merupakan suatu kegiatan investasi atau transaksi pembiayaan yang berdasarkan kepercayaan dari masing-masing pihak. Kepercayaan adalah unsur paling penting yang harus dijaga dalam akad mudharabah, yakni kepercayaan (amanah) dari pemilik modal kepada pengelola dana (mudharib). Keuntungan yang diperoleh dari usaha tersebut dibagi antara pemilik modal (shahib al-maal) dan pengelola dana (mudharib) berdasarkan nisbah yang telah disepakati oleh masing-masing pihak diawal akadnya. Kemudian apabila terjadi kerugian dari usaha itu, maka akan ditanggung sepenuhnya oleh pemilik modal (shahib al-maal), kecuali jika pengelola dana (mudharib) melakukan kesalahan yang disengaja, lalai atau menyalahi perjanjian yang telah disepakati para pihak.

Secara umum akad mudharabah dibagi menjadi 2 (dua) macam, yaitu: (1) Mudharabah Muthlaqah, ialah akad mudharabah yang sifatnya mutlak dimana shahib al-maal tidak menetapkan restriksi atau syarat-syarat tertentu kepada mudharib. (2) Mudharabah Muqayyadah, yakni pemilik modal (shahib al-maal) membatasi atau memberi syarat kepada pengelola dana (mudharib) dalam pengelolaan modalnya, misalnya hanya untuk menjalankan mudharabah pada sektor tertentu, waktu, cara ataupun tempat tertentu saja (Antonio, 1999). Dalam hal pembatasan ini seringkali mencerminkan bahwa pemilik modal (shahib al-maal) memasuki dunia usaha atau ikut campur dalam menjalankan usahanya.

Menurut KHES (Kompilasi Hukum Ekonomi Syariah), bahwasannya rukun dari akad mudharabah itu ada 3 (tiga), antara lain: Pertama, Shahib almaal (pemilik modal); Kedua, Mudharib (pelaku usaha); Ketiga, Akad. Adapun rukun dalam akad mudharabah menurut Jumhur Ulama adalah: Pertama, Dua orang yang melakukan akad (al-aqidani); Kedua, Modal (ma'qud 'alaih); Ketiga, Sighat akad (ijab dan qabul) (Naf'an, 2014). Sedangkan syarat-syarat dari mudharabah berdasarkan Kompilasi Hukum Ekonomi Syariah (KHES) antara lain: "(1) Pemilik modal wajib menyerahkan dana dan atau barang 
yang berharga kepada pihak lain untuk melakukan kerjasama dalam usaha; (2) Penerima modal menjalankan usaha dalam bidang yang disepakati; (3) Kesepakatan bidang usaha yang akan dilakukan ditetapkan dalam akad".

Setiap hal yang menjadi isi perjanjian yang disepakati oleh masingmasing pihak haruslah jelas tentang apa maksud dan makna yang dicantumkan dalam perjanjian tersebut, sehingga nantinya tidak menimbulkan terjadinya kesalahpahaman diantara para pihak yang menandatangani perjanjikan itu di kemudian hari. Pihak-pihak yang membuat perjanjian atau yang mengikatkan diri dalam perjanjian itu, ketika penerapan atau pelaksanaannya perjanjian haruslah mempunyai interpretasi yang sama mengenai apa yang telah mereka sepakati bersama dalam perjanjian, baik terhadap substansi perjanjian ataupun akibat hukum yang ditimbulkan dari perjanjian itu (Musjtari, 2012).

Mengenai akibat hukum dari meninggalnya mudharib dalam akad pembiayaan mudharabah, sebagaimana dijelaskan pada Buku II Bab VIII Pasal 209 Kompilasi Hukum Ekonomi Syariah (KHES) "Akad mudharabah berakhir dengan sendirinya jika pemilik modal atau mudharib meninggal dunia, atau tidak cakap melakukan perbuatan hukum".

Berdasarkan ketentuan dari Buku II Bab VIII Pasal 209 Kompilasi Hukum Ekonomi Syariah (KHES) ini dapat ditarik kesimpulan bahwa apabila mudharib (nasabah/pengelola dana) meninggal dunia dalam akad pembiayaan mudharabah, maka perjanjian yang dibuat antara shahib al-maal (bank sebagai pemilik modal) dengan mudharib (nasabah pengelola dana) menjadi berakhir sejak mudharib itu meninggal dunia. Maksudnya adalah bahwa hubungan hukum antara shahib al-maal (bank sebagai pemilik modal) dengan mudharib (nasabah pengelola dana) menjadi putus semenjak itu juga dan berakibat pula pada putusnya hak dan kewajiban diantara para pihak yang melakukan perjanjian tersebut.

Apabila mudharib (nasabah sebagai pengelola modal) meninggal dunia dalam suatu akad pembiayaan mudharabah, maka pelaksanaan dari akad mudharabah itu akan menimbulkan permasalahan atau hambatan, bahkan dimungkinkan mengalami kemacetan dan tentu secara tidak langsung ini merupakan suatu kerugian bagi pihak bank sebagai pemilik modal (shahib almaal). Akan tetapi, meninggalnya pengelola dana (mudharib) merupakan suatu kondisi yang berada di luar kemampuan manusia (overmacht) yang mengakibatkan pelaksanaan akadnya tidak dapat tercapai sesuai dengan tujuan awalnya. Secara prinsipnya segala bentuk risiko dan kerugian yang timbul dalam akad mudharabah akan ditanggung sepenuhnya oleh pemilik modal (shahib al-maal) yang mana dalam hal ini adalah pihak bank syariah, kecuali apabila nasabah pengelola dana (mudharib) tersebut terbukti 
melakukan kesalahan yang disengaja, kelalaian dan pelanggaran perjanjian yang telah disepakati oleh masing-masing pihak sebelumnya (Alfie, 2007).

Akan tetapi, dalam praktik dunia Perbankan Syariah sakarang ini tentu pihak bank syariah sebagai shahib al-maal tidak ingin mengalami kerugian begitu saja sebagai akibat dari meninggalnya mudharib (nasabah pengelola modal) dalam akad pembiayaan mudharabah. Meskipun secara prinsipnya akad mudharabah tersebut adalah suatu akad yang berlandaskan kepada kepercayaan (amanah) dari masing-masing pihak. Untuk mengantisipasi dari semua hal yang akan terjadi dalam akad mudharabah antara pihak bank syariah sebagai pemilik modal dengan nasabah sebagai pengelola dana, maka dalam praktiknya bank syariah selalu mewajibkan nasabah (mudharib) untuk mengasuransikan atas setiap pembiayaan yang diajukan nasabah kepada bank syariah tersebut. Setelah pihak asuransi menerbitkan polis asuransi jiwa atas nama nasabah (mudharib) yang mengajukan akad pembiayaan mudharabah, maka barulah bank syariah melakukan pencairan modal untuk dikelola oleh mudharib berdasarkan akad (kontrak) yang ditandatangani oleh para pihak.

Bank syariah sebagai lembaga keuangan juga terikat untuk melaksanakan prinsip kehati-hatian dalam menjalankan kegiatan usahanya sebagaimana yang diterapkan oleh bank konvensional, berdasarkan ketentuan dari Pasal 35 Ayat (1) Undang-Undang Nomor 21 Tahun 2008 tentang Perbankan Syariah (UUPS), agar bank syariah selalu dalam keadaan sehat, terjaga likuiditas dan solvabilitasnya. Kemudian dalam Pasal 36 Undang-Undang Nomor 21 Tahun 2008 tentang Perbankan Syariah menjelaskan bahwa, "Bank syariah dalam menyalurkan pembiayaan dan melakukan kegiatan usaha lainnnya wajib menempuh cara-cara yang tidak merugikan bank syariah, dan/atau unit usaha syariah dan kepentingan nasabah yang mempercayakan dananya". Jadi, pada hakikatnya prinsip kehati-hatian yang harus diperhatikan oleh bank syariah tersebut merupakan sebagai jaminan kepatuhan bank syariah terhadap semua ketentuan dan peraturan perundang-undangan yang berlaku (Muhammad, 2011).

\section{Status Sisa Pembayaran Pembiayaan Setelah Meninggalnya Mudharib dalam Akad Pembiayaan Mudharabah}

Pada dasarnya akad pembiayaan mudharabah bukanlah merupakan perjanjian utang-piutang maupun perjanjian pinjam-meminjam antara kreditur dengan debitur, akan tetapi merupakan suatu akad kerjasama antara pemilik modal (shahib al-maal) dengan pengelola dana (mudharib) untuk menjalankan suatu kegiatan usaha dengan sistem bagi hasil yang disepakati oleh masing-masing pihak. Kemudian kerugian dan risiko yang muncul dalam akad mudharabah ditanggung sendiri oleh bank sebagai 
pemilik modal (shahib al-maal), kecuali kerugian itu terjadi karena kelalaian, kesalahan yang disengaja dan pelanggaran perjanjian oleh mudharib. Sedangkan pengelola dana (mudharib) akan menanggung risiko pikiran, tenaga, waktu dan kesempatan memperoleh keuntungan finansial.

Bentuk skema dari akad mudharabah, yakni pihak calon pengelola dana (mudharib) mengajukan permohonan kepada bank syariah sebagai pemilik modal (shahib al-maal) untuk pembiayaan suatu usaha/proyek, sehingga kedua belah pihak memiliki keinginan untuk melakukan suatu transaksi dalam kegiatan ekonomi, dimana mudharib memiliki keahlian atau keterampilan dalam melakukan atau mengelola suatu usaha tersebut, sedangkan bank syariah mempunyai sumber dana (modal) untuk membantu pembiayaan suatu poyek/usaha itu. Masing-masing pihak mempunyai keinginan serta tujuan yang sama untuk kerjasama melaksanakan sebuah aktifitas ekonomi (proyek/usaha) demi mendapatkan laba/keuntungan, dimana keuntungan tersebut akan dibagi kepada masing-masing pihak berdasarkan nisbah yang disepakati diawal akad. Sehingga menimbulkan sebuah kesepakatan bersama dari para pihak yang dituangkan dalam suatu akad (kontrak), dimana perjanjian tersebut merupakan perjanjian bagi hasil yang dikenal dengan istilah mudharabah.

Ketika terjadi akad mudharabah tersebut pihak bank sebagai pemilik modal tidak diperkenankan mensyaratkan kepada calon nasabah (mudharib) untuk menanggung kerugian yang akan terjadi dalam kegiatan usahanya, karena mudharib merupakan orang yang mendapatkan amanah, sedangkan orang yang mendapatkan amanah tidak menanggung atas kerugian yang timbul. Sebagaimana dijelaskan dalam Pasal 210 Ayat (2) Kompilasi Hukum Ekonomi Syariah (KHES) bahwa "Kerugian yang diakibatkan oleh meninggalnya mudharib, dibebankan pada pemilik modal".

Menurut Jumhur Ulama jika salah satu pihak baik pemilik modal maupun pengelola dana (mudharib) meninggal dunia, maka akad mudharabah menjadi batal. Karena dalam akad mudharabah tersebut terdapat unsur wakalah, dan wakalah batal karena meninggalnya orang yang mewakilkan atau wakil (Muslich, 2013).

Pada saat pengelola dana (mudharib) meninggal dunia dalam akad pembiayaan mudharabah, maka akad mudharabah menjadi berakhir dengan sendirinya dan menyebabkan berakhir juga kewajiban mudharib untuk melakukan pembayaran kepada shahib al-maal. Maka, semenjak mudharib meninggal dunia tersebut pemilik modal (shahib al-maal) tidak diperkenankan lagi untuk melakukan penagihan atas pembiayaannya mudharib, karena semenjak itu telah putus hak dan kewajiban diantara mereka, dan begitu juga shahib al-maal tidak boleh menuntut ahli warisnya 
untuk membayar sisa pembayaran dari pembiayaannya karena mudharabah tersebut bukanlah perjanjian utang-piutang.

Mengenai agunan yang dahulunya dijadikan sebagai jaminan oleh nasabah pengelola dana (mudharib) kepada pihak bank syariah sebagai pemilik modal (shahib al-maal), maka agunan tersebut tidak dapat dilakukan pencairan dan disita oleh bank syariah (shahib al-maal) untuk menutupi sisa pembayaran pembiayaan yang belum dilakukan oleh mudharib yang disebabkan karena meninggalnya mudharib, kecuali nasabah pengelola dana (mudharib) tersebut terbukti melakukan penyimpangan dan melakukan pelanggaran terhadap hal-hal yang disepakati dalam akad sebelum mudharib itu meninggal dunia. Karena fungsi agunan pada akad mudharabah adalah untuk menjamin terlaksananya akad mudharabah dengan baik dan sesuai dengan kesepakatan yang telah dibuat diawal perjanjian antara shahib almaal dengan mudharib. Kemudian salah satu solusi bagi bank syariah sebagai pemilik modal (shahib al-maal) untuk mengembalikan modalnya kembali agar bisa menutupi sisa pembayaran pembiayaan yang belum dibayarkan oleh mudharib yang meninggal dunia adalah dengan menjual usaha yang dijalankan mudharib. Tetapi, jika usahanya masih berjalan ketika mudharib telah meninggal dunia, maka ahli warisnya dibolehkan untuk melanjutkan kembali usaha dari mudharib yang telah meninggal dunia dengan kesepakatan dan persetujuan dari shahib al-maal.

\section{KESIMPULAN}

Apabila mudharib (nasabah pengelola dana) meninggal dunia dalam akad pembiayaan mudharabah, maka perjanjian yang dibuat antara shahib almaal (bank sebagai pemilik modal) dengan mudharib (nasabah pengelola dana) menjadi berakhir sejak mudharib tersebut meninggal dunia. Maksudnya adalah bahwa hubungan hukum antara shahib al-maal (bank sebagai pemilik modal) dengan mudharib (nasabah pengelola dana) menjadi putus semenjak itu juga dan berakibat pula pada putusnya hak dan kewajiban diantara para pihak yang melakukan perjanjian tersebut. Sedangkan segala bentuk risiko dalam akad mudharabah ditanggung oleh shahib al-maal, kecuali jika nasabah pengelola dana (mudharib) terbukti melakukan kesalahan yang disengaja, kelalaian atau pelanggaran perjanjian yang telah disepakati sebelumnya.

Semenjak pengelola dana (mudharib) meninggal dunia dalam akad pembiayaan mudharabah, maka bank syariah sebagai pemilik modal (shahib al-maal) tidak diperkenankan lagi untuk melakukan penagihan atas pembiayaannya mudharib, karena semenjak meninggalnya mudharib tersebut telah berakhir hak dan kewajiban diantara mereka, dan begitu juga 
shahib al-maal tidak boleh menuntut ahli warisnya untuk membayar sisa pembayaran dari pembiayaannya karena mudharabah itu bukanlah perjanjian utang-piutang. Untuk mengembalikan modal dari pemilik modal (shahib al-maal) yang belum dibayarkan oleh mudharib yang telah meninggal dunia adalah dengan cara menjual usahanya mudharib, atau apabila usahanya masih berjalan, maka ahli warisnya diperbolehkan untuk melanjutkan usaha dari mudharib yang meninggal dunia tersebut dengan kesepakatan dari shahib al-maal.

\section{DAFTAR PUSTAKA}

Alfie, A. A. (2007). Analisis Kepatuhan Pembiayaan Mudharabah dalam Pernyataan Standar Akuntansi Keuangan (PSAK No. 59) terhadap Aspek Syariah Ilmu Fiqih Syafi'iyah. Jurnal Ekonomi dan Bisnis Vol. 2, No. 3 , h. 36.

Antonio, S. (1999). Bank Syariah Wacana Ulama dan Cendikiawan. Jakarta: Tazkia Institute.

Fatwa Dewan Syariah Nasional Nomor 07/DSN/MUI/IV/2000 tentang Pembiayaan Mudharabah.

Ibrahim, M. A. (2002). Konsep profit and loss sharing system Menurut Empat Mazhab. Jakarta: P3EI UIN Syarif Hidayatullah.

Karim, A. A. (2004). Bank Islam: Analisis Fiqih dan Keuangan. Jakarta: PT Raja Grafindo.

Kompilasi Hukum Ekonomi Syariah (KHES). (2010). Bandung: Fokus Media.

Muhammad. (2005). Konstruksi Mudharabah dalam Bisnis Syariah: Mudharabah dalam Wacana Fiqih dan Praktik Ekonomi Modern. Yogyakarta: BPFE Yogyakarta.

Muhammad, D. W. (2011). Kajian tentang Pembiayaan Mudharabah pada Bank Syariah. Jurnal Media Hukum , h. 33.

Musjtari, D. N. (2016). Rekonstruksi Lembaga Penyelesaian Sengketa Akad Pembiayaan Dengan Jaminan Hak Tanggungan Pasca Putusan Mahkamah Konstitusi Nomor 93/PUU-X/2012. Jurnal Media Hukum, 63.

Musjtari, D. N. (2012). Penyelesaian Sengketa dalam Praktik Perbankan Syariah. Yogyakarta: Parama Publishing.

Muslich, A. W. (2013). Fiqh Muamalat. Jakarta: Amzah.

Naf'an. (2014). Pembiayaan Musyarakah dan Mudharabah. Yogyakarta: Graha Ilmu.

Peraturan Bank Indonesia Nomor: 9/19/PBI/2007 tentang Pelaksanaan Prinsip Syariah dalam Kegiatan Penghimpunan Dana dan Penyaluran Dana Serta Pelayanan Jasa Bank Syariah.

Rusyd, I. Bidayah al-Mujathid. Mesir: Dar Al-Fkir.

Saeed, A. (2004). Menyoal Bank Syariah: Kritik Atas Interpretasi Bunga Bank Kaum Neo-Revivalis. Jakarta: Paramadina.

Soekanto, S. d. (2001). Penelitian Hukum Normatif: Suatu Tinjauan Singkat. Jakarta: Rajawali Pers. 
Sudarsono, H. (2004). Bank dan Lembaga Keuangan Syariah Deskripsi dan Ilustrasi. Yogyakarta: Ekonosia.

Sumitro, W. (2004). Asas-Asas Perkembangan Islam \& Lembaga-Lembaga Terkait. Jakarta: PT Raja Grafindo Persada.

Undang-Undang Nomor 10 Tahun 1998 tentang Perbankan.

Undang-Undang Nomor 3 Tahun 2004 tentang Bank Indonesia.

Undang-Undang Nomor 21 Tahun 2008 tentang Perbankan Syariah.

Yhu'nanda, M. A. (2014). Analisis Unsur Kesalahan dan Kelalaian Mudharib dalam Akad Pembiayaan Mudharabah Bermasalah Sebagai Dasar Eksekusi Jaminan. Kumpulan Jurnal Mahasiswa FH UB , h.4. 